\title{
Analisis Kompetensi Peran Pemimpin dalam Memberikan Pelayanan Sosial di LKSA Panti Asuhan Masyithoh Kota Lubuklinggau
}

\author{
Eka Nurwahyuliningsih ${ }^{1}{ }^{*}$, Soni Akhmad Nulhaqim ${ }^{1}$
}

${ }^{1}$ Universitas Padjajaran, Indonesia

\author{
A R T I C L E I N F O \\ Article history: \\ Received 18 November 2020 \\ Accepted 04 Februari 2021 \\ Available online 30 Juni 2021 \\ Kata Kunci: \\ Kompetensi Pemimpin; \\ Organisasi Pelayanan \\ Manusia; Panti Asuhan \\ Masyithoh \\ Keywords: \\ Leader Competency; Human \\ Service Organization; \\ Masyithoh Orphanage.
}

\begin{abstract}
A B S T R A K
Setiap organisasi pelayanan kemanusiaan memerlukan sosok pemimpin yang dapat memimpin lembaga dengan baik serta dapat memberikan dan mengembangkan kualitas pelayanan sosial yang efektif dan efisien. Seorang pemimpin harus memiliki kompetensi administrator sebagai penunjang keberlangsungan dalam melaksanakan peranannya. Kompetensi yang harus dimiliki oleh seorang pemimpin yakni pengetahuan, sikap dan tindakan. Peran seorang pemimpin seringkali dilihat sebagai faktor utama dalam mengkoordinasikan dan menyelaraskan proses organisasi lembaga. Penelitian ini bertujuan untuk mengetahui peran pemimpin dalam memberikan pelayanan sosial di LKSA Panti Asuhan Masyithoh ditinjau dari kompetensi administrator pekerjaan sosial menurut teori Skidmore. Metode penelitian yang digunakan adalah metode kualitatif yang bersifat deskriptif. Hasil penelitian yang telah dilakukan yakni pemimpin panti mampu berkomitmen dan berdedikasi menjalankan tugasnya dengan baik serta ketika menjalankan
\end{abstract} tugasnya sebagai seorang pemimpin, pemimpin panti telah menerapkan kompetensi administrator pekerjaan sosial. Ketiga kompetensi yang dimiliki oleh seorang pemimpin menjadi perpaduan yang utuh untuk memberikan pelayanan sosial kepada penerima manfaat, yakni anak-anak yang berada di LKSA Panti Asuhan Masyithoh.

\begin{abstract}
A B S T R A C T
Human service organizations need a leader who can lead the institution well and provide and develop quality social services that are effective and efficient. A leader must have administrator competence as a support for sustainability in carrying out his role. Competencies that a leader must possess are knowledge, attitudes, and actions. The role of a leader is often seen as a significant factor in coordinating and harmonizing institutional, organizational processes. According to Skidmore's theory, this study aims to determine the role of leaders in providing social services in LKSA Masyithoh Orphanage in terms of the competence of social work administrators. The research method used is a descriptive qualitative method. The research results that have been carried out are that the orphanage leader can be committed and dedicated to carrying out their duties properly, and when carrying out their duties as a leader, the leader of the orphanage has implemented the competence of social work administrators. A leader's three competencies become a complete combination to provide social services to beneficiaries, namely children in the LKSA Masyithoh Orphanage.
\end{abstract}

Copyright (c) Universitas Pendidikan Ganesha. All rights reserved.

Corresponding author.

E-mail addresses: eka20003@mail.unpad.ac.id 


\section{Pendahuluan}

Organisasi pelayanan kemanusiaan di Indonesia berkembang cukup pesat, artinya perkembangan ini membawa pengaruh yang baik untuk membantu mengatasi masalah sosial. Sebagaimana yang kita ketahui bahwa kesejahteraan sosial mencakup pelayanan-pelayanan sosial yang terdapat di masyarakat sebagai upaya atau tindakan dalam membantu mengatasi permasalahan agar dapat terjalin sebuah keberfungsian sosial seseorang baik secara individu, kelompok maupun masyarakat.

Berdasarkan pendapat Hasenfeld, (2010:19) Human service organizations are seen as a symbol of concern and embodiment of community obligations for the well-being of fellow citizens. Pelayanan sosial kemanusiaan dipandang sebagai suatu simbol dan ciri dari kepedulian pemerintah maupun masyarakat kepada kesejahteraan masyarakat lainnya yang membutuhkan bantuan untuk dapat memenuhi kebutuhan sosial.

Berbicara organisasi pelayanan kemanusiaan tidak terlepas dari manajemen dan administrasi. Dalam hal ini, administrasi dapat dikatakan sebagai suatu penggerak untuk mengambil keputusan serta dapat digunakan sebagai evaluasi kegiatan yang telah dilakukan. Menurut Skidmore (1995:1) Administrasi diakui sebagai komponen penting dalam memberikan layanan sosial. Administrasi biasanya dikontrol oleh para pemimpin diatasnya yang memfasilitasi kerja lembaga dan staf. Aspek kepemimpinan menjadi salah satu poin penting dalam penguatan kelembagaan dan juga dalam meningkatkan kualitas pelayanan lembaga. Kemudian seorang administrator yang kompeten dapat membuat badan pelayanan sosial efektif dan efisien. Administrator yang cakap dapat menghasilkan yang diinginkan; dan pemimpin yang tidak kompeten dapat memblokir layanan dan menggagalkan staf. Oleh karena itu, dibutuhkan peran pemimpin yang dapat memberikan perubahan demi tercapainya tujuan lembaga.

Menurut Packard, (2020:143) Leadership is recognized as representing a significant variabel that can affect the quality of institutional performance.Peran pemimpin menjadi nilai penting dalam perkembangan lembaga pelayanan sosial. Sesuai dengan pendapat Alfiyah \& Syafriani, (2019:38) Pemimpin dikatakan dapat mengubah sebuah lembaga untuk mempunyai masa depan yang lebih baik serta berkembang sekaligus mampu memberikan pengaruh kepada anggotanya untuk melakukan peran dan tanggungannya sesuai dengan aturan yang berlaku. Seorang pemimpin harus berperan aktif dalam memberikan pelayanan sosial, sehingga mengharuskan baginya untuk mempunyai kemampuan leadership dan kinerja yang baik.

Konsep kepemimpinan yang baik adalah pemimpin yang mampu dan dapat mengelola sumber daya lembaga pelayanan sosial untuk mencapai tujuannya. Suparno, (2012) berpandangan bahwa Seorang pemimpin perlu memiliki pemahaman yang luas tentang beragam pengetahuan meskipun pemahamannya tidak secara komprehensif. Bagi seorang pemimpin pengetahuan tersebut akan menjadi acuan dalam pengambilan keputusan. Kepemimpinan dapat dikatakan efektif apabila mampu menciptakan situasi yang dapat memberi inspirasi bagi para pengikutnya untuk mencapai tujuan yang lebih baik dan lebih maju lagi dari keadaan sekarang. Tidak hanya memiliki pengetahuan, seorang pemimpin harus memiliki sikap dan tindakan yang digunakan untuk menciptakan iklim organisasi yang baik, hal ini ditujukan agar dapat mencapai sasaran yaitu meningkatkan kualitas pelayanan pada lembaga pelayanan sosial. Ketiga komponen tersebut dapat mempengaruhi dalam menjalankan tugasnya serta menjadi indikator keberhasilan seorang pemimpin dalam memberikan pelayanan di lembaga pelayanan sosial kemanusiaan.

Lembaga Kesejahteraan Sosial Anak Panti Asuhan Masyithoh merupakan salah satu organisasi pelayanan kemanusiaan (Human services organization) berperan untuk memberikan perlindungan kepada anak serta dapat memenuhi hak-hak anak yang sebelumnya mereka tidak mendapatkan pemenuhan hak tersebut. Lembaga telah melaksanakan program untuk membantu pemerintah dalam bidang kesejahteraan sosial anak. Panti Asuhan Masyithoh mengasuh dan membina anak-anak serta memberikan pendidikan formal dari tingkat sekolah dasar sampai 
dengan sekolah menengah atas. Selain pendidikan formal, anak-anak juga mendapatkan pendidikan keagamaan yang kuat karena semua anak mendapatkan pendidikan di pondok pesantren Ittihaadul Ulum secara gratis. Mereka dibekali keterampilan, diantaranya keterampilan teknologi dan komputer, menjahit, percetakan sablon, bercocok tanam, dan peternakan.

Pada penelitian ini akan menganalisis bagaimana peran pemimpin dalam memberikan pelayanan sosial di Lembaga Kesejahteraan Sosial Anak Panti Asuhan Masyithoh Kota Lubuklinggau ditinjau dari kompetensi administrator pekerjaan sosial. Penelitian ini sejalan dengan teori Skidmore tentang Administrasi Pekerjaan Sosial. Teori tersebut menjelaskan bahwa administrasi pekerjaan sosial merupakan salah satu komponen penting dalam memberikan pelayanan sosial dan juga menjadi suatu proses dalam menjalankan lembaga yang melibatkan tujuan, kebijakan, staf, manajemen, layanan dan evaluasi.

\section{Metode}

Penelitian ini menggunakan metode penelitian kualitatif yang bersifat deskriptif yakni memberikan gambaran terhadap peran pemimpin dari Lembaga Kesejahteraan Sosial Anak Panti Asuhan Masyithoh dalam memberikan pelayan sosial ditinjau dari kompetensi administrator pekerjaan sosial. Menurut Creswell (2004:4) penelitian kualitatif yaitu metode-metode untuk mengeksploarasi dan memahami makna yang oleh sejumlah individu atau sekelompok orang dianggap berasal dari masalah sosial atau kemanuasiaan". Informan pada penelitian ini adalah Kepala LKSA Panti Asuhan Masyithoh, pengurus dan pendidik yang ada di lingkungan LKSA Panti Asuhan Masyithoh. Peneliti memilih sendiri informan dalam wawancara ini menggunakan cara purposive sampling. Purposive sampling menurut Soehartono (2011:63) adalah pengambilan sampel berdasarkan tujuan yaitu informan yang diambil sebagai anggota sampel diserahkan pada pertimbangan pengumpulan data menurutnya sesuai dengan maksud dan tujuan penelitian, yang mana tujuan pemilihan informan yakni untuk memperoleh informasi secara komprehensif. Teknik pengumpulan data yang digunakan dalam penelitian ini yaitu observasi, wawancara mendalam (in dept interview), dan studi dokumentasi.

Setelah memperoleh data dari observasi dan wawancara dengan kepala panti asuhan masyithoh serta staf panti asuhan, maka peneliti menganalisis data yang telah diperoleh dari hasil wawancara dan catatan lapangan. Menurut Ahyar, dkk., (2020:162) analisis data adalah suatu proses mencari dan menyusun secara sistematis data yang didapatkan dari hasil wawancara, catatan lapangan, dan dokumentasi, kemudian mengorganisasikan data ke dalam kategori, menjabarkan ke dalam unit-unit, melakukan sintesa, menyusun ke dalam pola, memilih mana yang penting dan yang akan dipelajari, dan membuat simpulan sehingga mudah dipahami oleh diri sendiri maupun orang lain. Menurut Miles dan Huberman (1992) Terdapat tiga tahapan yang digunakan oleh peneliti dalam menganalisis data yakni Reduksi data, Pada bagian ini peneliti menggolongkan, mengarahkan, membuang data yang tidak perlu, dan mengorganisasi data dengan cara sedemikian rupa hingga simpulan-simpulan akhirnya dapat ditarik dan diverifikasi; Penyajian data, hasil wawancara dan sekunder disusun secara sistematis agar mudah bagi peneliti untuk memahami data yang didapat dari lapangan yakni data informasi tentang pemimpin dan panti asuhan masyithoh; serta Kesimpulan, yakni interpretasi atau tafsiran data yang sudah disajikan oleh peniliti.

\section{Hasil dan pembahasan}

Panti Asuhan Masyithoh yang berada dibawah naungan Yayasan Darma merupakan salah satu lembaga perlindungan anak yang memiliki fungsi untuk memberikan perlindungan terhadap anak-anak yang mempunyai permasalahan sosial dan mencoba turut serta untuk membantu mengatasinya. Adapun Penghuni panti asuhan masyithoh yakni mulai dari anak-anak hingga orang dewasa yang memiliki berbagai permasalahan sosial dan kehidupan (yatim piatu, kurang mampu 
dan permasalahan keluarga/broken home). Sebagai lembaga sosial, Panti Asuhan Masyithoh telah memiliki legalitas yang terdaftar di Kementerian Sosial dan Dinas Sosial Provinsi Sumatera Selatan serta Dinas Sosial Kota Lubuklinggau. Panti Asuhan Masytithoh memiliki struktur organisasi meliputi Pimpinan Panti, Wakil Pimpinan Panti, Sekretaris, Bendahara, Bidang Pendidikan, Bidang Keagamaan, Bidang Kesehatan, Humas dan Pengurus.

LKSA Panti Asuhan Masytihoh memiliki visi memberikan pelayanan, pemenuhan kebutuhan fisik, sebagai tempat kelangsungan hidup dan tumbuh berkembang anak-anak terlantar yang diharapkan nantinya mereka dapat hidup secara mandiri dan mampu bersaing dengan anak-anak lain yang notabenenya masih mempunyai orang tua serta berkecukupan. Serta memiliki misi pengasuhan di Panti Asuhan Masyithoh lebih memfokuskan pada terpenuhinya pendidikan anak sebagai modal masa depan yang berarti dan bermanfaat sebab pendidikanlah yang dianggap sangat berpengaruh dalam perubahan masa depan tanpa pendidikan maka tidak akan berarti banyak pertolongan yang kita berikan. Jumlah anak yang berada di LKSA Panti Asuhan Masyithoh yaitu 80 orang, diantaranya 36 anak laki-laki dan 44 anak perempuan, dengan jumlah pengurus 11 orang sudah termasuk dengan pemimpin.

Berdirinya suatu lembaga pelayan sosial tidak bisa lepas dari peran semua pihak. Peran yang paling dominan dalam hal ini adalah peran seorang pemimpin, yang mana pemimpin memiliki peran paling besar dalam memajukan dan mengembangkan pelayanan sosial. Menurut Obsorne, (2015:7) leadership attends an ability that a person develops to form an environment, where all parties know what contribution is expected and be able to commit to doing their job well. For a manager, leadersgup obtains a significant skill to gain in a structured manner. Denga kata lain, kepemimpinan hadir sebagai kemampuan yang dikembangkan seseorang untuk membentuk lingkungan, di mana semua pihak tahu kontribusi apa yang diharapkan dan mampu berkomitmen untuk melakukan pekerjaan mereka dengan baik. Bagi seorang manajer, leadergup memperoleh keterampilan yang signifikan untuk diperoleh secara terstruktur. Baik dalam organisasi layanan manusia maupun diluar organisasi tersebut, pemimpin memiliki peranan penting untuk menggerakan serta mengarahkan anggota organisasi untuk mencapai tujuannya serta berntribusi untuk melakukan pekerjaan dengan baik.

Selain itu seorang pemimpin harus memiliki jiwa kepemimpinan yang didukung oleh kompetensi administrator. Hal ini sangat membantu pemimpin dalam menjalankan peran dan tugasnya serta dapat menambah kualitas kinerja pemimpin memberikan pelayanan di lembaga pelayanan sosial kemanusiaan. Adapun kompetensi tersebut menurut Skidmore meliputi, pengetahuan yang terdiri dari delapan aspek; sikap terdiri dari enam aspek; serta tindakan mencakup delapan belas aspek. Dalam penelitian yang dilakukan, ketiga kompetensi di atas digunakan dalam menganalisis peran pemimpin. Namun tidak semua aspek didalamnya dipakai, hanya beberapa aspek saja yang dianggap peneliti mampu menunjang kompetensi yang harus dimiliki seorang pemimpin dalam memberikan pelayanan di lembaga pelayananan sosial kemanusiaan.

\section{Pengetahuan}

Skidmore (1995), mengatakan bahwa pengetahuan yang memadai tentang administrasi sangat penting untuk operasi yang efektif dari sebuah agen pekerjaan sosial. Dalam aspek pengetahuan seorang administrator pekerja sosial harus mengetahui tujuan, kebijakan, pelayanan serta sumber daya dari lembaga; Memiliki pengetahuan dasar tentang dinamika tingkah laku manusia; Memiliki pengetahuan tentang sumber daya masyarakat, terutama yang berhubungan dengan lembaganya; Mengetahui metode-metode pekerja sosial yang digunakan di lembaga; Mengetahui prinsip, proses dan teknik manajemen; Mengenal baik asosiasi-asosiasi pekerjaan sosial profesional; dan Memahami teori keorganisasian. 
Pengetahuan yang dimiliki oleh pemimpin di LKSA Panti Asuhan Masyithoh selaras dengan pengetahuan administrasi pekerjaan sosial. Pimpinan LKSA Panti asuhan Masyithoh berpendapat bahwa seorang pemimpin harus selayaknya kaya akan pengetahuan yang dimiliki, hal ini demi menunjang keberlangsungan ketika mempimpin suatu lembaga, terutama lembaga pelayanan sosial.

1) Mengetahui tujuan, kebijakan, pelayanan, serta sumber daya dari lembaga.

Menurut pandangan informan bahwa dalam memimpin suatu lembaga pentingnya seorang pemimpin memiliki pengetahuan terkait dengan tujuan yang jelas. Tujuan tersebut harus direncanakan sedemikian mungkin agar dapat tercapai sesuai dengan harapan. Selain itu kepala panti asuhan memiliki kebijakan yang menjadi pedomannya untuk melaksanakan kegiatan, pedoman tersebut menjadi dasar dalam pengambilan keputusan lembaga. Pelayanan yang diberikan sesuai dengan visi dan misi Panti Asuhan Masyithoh. Menurutnya, bahwa sebisa mungkin lembaga harus memberikan pelayanan yang maksimal kepada anak-anak, karna dengan memaksimalkan pelayanan yang ada dapat memberi kepuasan kepada anakanak tersebut, hak dan kewajiban anak dapat terpenuhi dan anak dapat menjalani kehidupan sehari-harinya dengan bahagia pastinya. Tidak hanya itu, dengan memaksimalkan pelayanan dapat memberikan pengaruh yang baik bagi perkembangan panti asuhan. Selain itu juga, menurut pandangan informan sangat penting memiliki sumber daya manusia yakni SDM yang unggul, inovatif dan kreatif ini sangat membantu proses perkembangan panti asuhan, tanpa adanya SDM panti tidak dapat berkembang menuju ke tahap yang diinginkan. Sumber daya manusia dan sumber daya materil menjadi faktor penting dalam menjalankan lembaga pelayanan kemanusiaan.

2) Memiliki pengetahuan yang luas tentang sumber daya masyarakat, terutama yang berhubungan dengan lembaga.

Pengetahuan tentang sumber daya masyarakat menjadi hal yang cukup signifikan yang harus dimiliki oleh seorang pemimpin. Pimpinan panti asuhan masyithoh memiliki hubungan yang harmonis dengan masyarakat yang berada di sekitar panti. Hubungan yang baik menimbulkan dukungan positif yang diberikan oleh masyarakat.

3) Mengetahui prinsip, proses dan teknik manajemen.

Selama menjadi pimpinan panti asuhan masyithoh, kepala panti selalu berpegang teguh pada prinsip yang ada. Awal mula berdirinya panti asuhan masyithoh ini karena adanya keresahan yang dialami oleh pendiri panti terhadap anak-anak yang menjadi penyandang masalah sosial diperkirakan tidak mampu untuk memperoleh penghidupan dan pendidikan serta keterampilan langsung dari keluarganya. Prinsip yang selalu dipegang teguh yakni bagaimana panti ini dapat berkembang dengan baik. Perkembangan panti asuhan erat kaitannya dengan proses yang dilalui, pastinya proses yang dilalui tidak mudah banyak tantangan yang harus dihadapi. Menurut pandangan kepala panti, pentingnya bagi pemimpin untuk mengetahui tentang manajemen konflik, karna setiap orang akan berhadapan dengan konflik. Hal itu membuat seorang pemimpin harus menguasai teknik manajemen yang baik. Ke tiga hal tersebut sangat membantu dalam mengelola manajemen panti asuhan masyithoh.

\section{Sikap}

Berdasarkan pandangan Skidmore (1995:37) Selain pengetahuan substantif, administrator pekerjaan sosial yang kompeten memiliki sekelompok sikap profesional yang penting dalam menjalankan hubungan dengan staf dan masyarakat. Sikap adalah kecenderungan untuk bertindak dan terkait dengan perasaan orang yang sangat penting dalam proses administrasi. Beberapa sikap yang harus dimiliki oleh administrator pekerja sosial yakni: 
1) Administrator menghormati tiap anggota tim sebagai individu yang memiliki kekhasan

Memimpin sebuah lembaga pelayanan sosial tidak terlepas dari dukungan anggota. Panti asuhan masyithoh terdapat pengurus dan pendamping yang membantu keberlangsungan aktivitas lembaga. Dimana setiap staf atau anggota memiliki keunikan tersendiri, mengingat bahwa semua manusia memiliki ciri khas yang menjadi pembeda dengan manusia lainnya. Kepala panti asuhan sangat menghormati pengurus dan pendamping, hal ini menjadi sesuatu yang penting untuk menghargai setiap individu. Saling menghormati antar anggota dapat menimbulkan kualitas hubungan yang harmonis diatara sesama.

2) Administrator mengetahui bahwa tidak ada seorang pun yang sempurna dan menerima hal ini bagi tim dan dirinya.

Pada dasarnya tidak ada manusia yang sempurna, begitu juga dengan anggota staf di panti asuhan masyithoh. Ketidaksempurnaan yang ada dapat menjadi kekuatan untuk mengembangkan pelayanan panti asuhan, kepala panti asuhan menyadari bahwa ketidaksempurnaan menjadi sesuatu yang harus terus dilengkapi hal ini mendorong agar diantara pengurus maupun pendamping dapat saling memahami dan menerima satu dengan lainnya. Menurut informan, sudah seharusnya seorang pimpinan memiliki sikap seperti ini yakni saling memahami ketidaksempurnaan karena hal itu menjadi sesuatu yang harus dimaklumi dalam bekerja dengan orang lain.

3) Administrator memiliki pikiran terbuka dan menerima ide-ide baru dan kenyataan-kenyataan. Kepala panti asuhan masyithoh sangat terbuka akan ide dan gagasan yang diberikan oleh anggota staf. Ide dan gagasan tersebut dapat memberikan angin segar dalam keberlangsungan pelayanan panti asuhan kedepannya. Pemimpin pada zaman sekarang harus lebih menerima ide, gagasan serta saran dan masukan dari anggota staf, tidak selalu harus pemimpin yang memberikan ide maupun gagasan untuk mengembangkan pelayanan panti asuhan.

4) Administrator mengetahui bahwa kesejahteraan lembaga lebih penting daripada kesejahteraan pekerja lainnya, termasuk administrator itu sendiri

Namun menurut pandangan pemimpin panti asuhan masyithoh, tidak hanya kesejahteraan lembaga yang harus diutamakan melainkan kesejahteraan pengurus dan pendamping perlu didahulukan dan diperhatikan. Loyalitas atau tidaknya anggota staf panti asuhan tergantung dari bagaimana sikap yang diberikan oleh pemimpin dan lembaga pelayanan tersebut. Jika pemimpin memberikan sikap yang baik kepada anggota stafnya setidaknya hal tersebut tidak akan terjadi, apabila terjadi maka dapat mengganggu perkembangan pelayanan panti asuhan. Hal tersebut dapat dikatakan bahwa kesejahteraan lembaga tergantung bagaimana sikap seorang pemimpin kepada anggota stafnya.

\section{Tindakan}

Skidmore (1995) tidak hanya mempunyai pengetahuan dan sikap profesional, administrator pekerjaan sosial harus mampu untuk berperan serta melakukan banyak tindakan manajerial. Nyatanya, administrator pekerjaan sosial yang cakap hampir sepanjang waktu bergerak dalam berbagai cara.

1) Penerimaan (Accepting)

Administrator pekerjaan sosial secara realistis menerima staf dan klien sebagaimana adanya, serta pemimpin yang profesional di organisasi tempat dia bekerja.

Selama bekerja dan menjadi kepala lembaga, menurut informan kepala panti dan manajemen panti asuhan masyithoh menerima staf apa adanya tanpa membedakan dengan staf lainnya. Adapun pengurus dan pendamping panti asuhan merupakan alumni dari panti asuhan masyithoh dan juga ada beberapa pengurus yang berasal dari pondok pesanteren dari Yayasan Darma. Tindakan ini membuat pengurus maupun pendamping merasa diterima secara baik oleh panti asuhan, hal ini dapat menimbulkan hubungan yang solid atara pemimpin dengan 
anggotanya. Anggota staf panti asuhan masyithoh selama dibawa pimpinan kepala panti sekarang merasa tidak ada pembedaan atau perbandingan antara sesama. Dengan adanya penerimaan yang baik dari seorang pimpinan membuat kinerja pengurus dan pendamping panti asuhan masyithoh menjadi meningkat.

2) Perhatian (Caring)

Selama memimpin panti asuhan masyithoh, kepala panti asuhan selalu memberikan perhatian kepada pendamping maupun pengurus dan juga kepada anak-anak yang berada di panti asuhan. Menurut informan, perhatian atau caring menjadi suatu hal yang harus dimiliki oleh seorang pemimpin. Dengan adanya tindakan kepedulian membuat anggota maupun anak-anak merasa dicintai dan disayangi serta diakui keberadaanya. Tindakan yang dimaksud menjadi keharusan yang perlu dipahami dan dilakukan oleh seorang pemimpin.

3) Kepercayaan (Trusting)

Kepala panti asuhan masyithoh selalu menerapkan kepercayaan kepada pengurus maupun kepada pendamping. Beliau percaya akan tindakan yang dilakukan oleh anggota stafnya, serta menghargai pandangan dan gagasan yang diberikan oleh pengurus maupun pendamping. Adanya kepercayaan dapat membuat semua kegiatan dapat berlangsung dengan lebih mudah. Ketika ada kegiatan di panti asuhan masyithoh, kepala panti selalu memberikan tanggung jawab kepada pengurus maupun pendamping untuk menangani kegiatan yang dilaksanakan. Hal ini menjadi bentuk tindakan yang dilakukan oleh seorang pemimpin kepada anggotanya yakni memberikan kepercayaan yang seluas-luasnya.

4) Perencanaan (Planning)

Seorang pemimpin harus mempunyai suatu rencana yang akan digunakan untuk menentukan tujuan lembaga pelayanan sosial. Perencanaan yang baik harus memiliki tujuan yang sesuai dengan visi dan misi lembaga. Hal tersebut juga dilakukan oleh kepala panti asuhan masyithoh, perencanaan yang dilakukan bertujuan untuk mencapai target lembaga yakni untuk meningkatkan kualitas pelayanan panti asuhan masyithoh.

Ketika proses perencanaan kegiatan panti asuhan, kepala panti selalu melibatkan pengurus dan pendamping. Keduanya didorong untuk dapat memberikan sumbangsih rencana demi mencapai tujuan lembaga panti asuhan masyithoh secara keseluruhan. Menurut pendapat kepala panti asuhan masyithoh, perencanaan sama halnya dengan aktivitas untuk merumuskan sesuatu yang akan dikerjakan dengan sumber daya yang dimiliki.

5) Pengorganisasian (Organizing)

Pembagian tugas atau yang dikenal dengan pengorganisasian sangat erat hubungannya dengan tindakan yang harus dilakukan oleh pimpinan. Selama memegang peranan menjadi seorang pemimpin, kepala panti asuhan masyithoh harus mengetahui proses pembagian tugas serta wewenang untuk mencapai tujuan lembaga panti asuhan masytihoh. Menurut informan, Ia selalu melakukan pembagian tugas kepada pendamping dan pengurus sesuai dengan kemampuan dan pengetahuan yang mereka miliki. Menurutnya, proses pengorganisasian bukan merupakan hal yang mudah dilakukan. Hal ini membutuhkan kerjasama yang baik antara anggota lembaga.

6) Menentukan Prioritas (Setting Priorities)

Kepala panti ditutut harus mampu untuk menentukan prioritas yang akan dipilih untuk kelangsungan kegiatan di panti asuhan masyithoh. Ketika menentukan prioritas, kepala panti terlebih dahulu mengidentifikasi hal mana yang menjadi prioritas utama. Kemudian setelah mengidentifikasi hal tersebut, pimpinan panti akan mempertimbangkan sesuatu yang telah dipilih untuk tujuan jangka pendek maupun jangka panjang. Sama halnya ketika diharuskan menentukan prioritas utama dalam setiap pekerjaan yang harus dikerjakan oleh pimpinan. Tindakan ini menjadi hal penting bagi seorang pemimpin. 
7) Berinteraksi dengan masyarakat dan profesi pemberi bantuan

Interaksi menjadi sesuatu yang sangat signifikan yang harus dimiliki oleh seorang pemimpin. Kepala panti juga menjalin hubungan yang baik dengan masyarakat sekitar. Bukan hanya itu saja, kepala panti asuhan maupun pengurus dan pendamping menjalin relasi yang baik dengan donatur panti. Menurut informan, adanya relasi yang baik diantara kedua pihak ini menjadi suntikan semangat untuk kami semua dalam menjalankan tugasnya yakni memberikan pelayanan sosial bagi anak-anak yang berada di panti asuhan masyithoh.

8) Pembuatan keputusan (Decession making)

Banyak faktor yang harus diketahui oleh seorang pemimpin dalam membuat suatu keputusan, apalagi jika ada hubungannya dengan lembaga. Dalam membuat keputusan harus difikirkan secara matang karena seorang pemimpin harus mengetahui baik buruk keputusan yang akan diambil, kemudian perlunya melakukan diskusi kepada anggota staf. Dengan begitu dapat memungkinkan keputusan yang diambil dapat diterima oleh semua pihak dan keputusan tersebut baik untuk perkembangan lembaga. Menurut informan, dalam pembuatan keputusan, Ia selalu melibatkan pendamping maupun pengurus dalam proses pengambilan keputusan, hal ini bertujuan agar mereka mengetahui keputusan yang telah diambil untuk perkembangan panti asuhan.

9) Komunikasi (Communicating)

Kemampuan komunikasi menjadi suatu aspek penting dalam menjalankan lembaga pelayanan sosial, artinya komunikasi menjadi suatu kunci yang sangat berguna bagi kepala panti dalam keberlangsungan menjalani hubungan dengan semua pihak. Kepala panti asuhan masyithoh selalu menjalin komunikasi yang baik kepada pengurus, pendamping maupun kepada anakanak panti. Dengan adanya komunikasi yang efektif memudahkan mereka mengerti apa yang ingin disampaikan dan lakukan, artinya dengan komunikasi yang dilakukan membuat pesan tersebut diterima dengan baik oleh semua pihak.

10) Memotivasi (Motivating)

Menurut pandangan kepala panti asuhan masyithoh, sebelum memotivasi orang lain baiknya terlebih dahulu kita dapat memotivasi diri sendiri untuk melangkah lebih baik. Jika sudah dapat memotivasi diri sendiri, maka secara langsung dapat memotivasi orang lain. Ketika menjalani peran seorang pemimpin di panti asuhan masyithoh, tidak jarang beliau selalu memberikan dorongan kepada pendamping maupun pengurus untuk meningkatkan kemampuan mereka dalam memberikan pelayanan di panti asuhan masyithoh.

Konsep kepemimpinan yang baik adalah pemimpin yang mampu dan dapat mengelola sumber daya lembaga pelayanan sosial untuk mencapai tujuannya. Suparno, (2012) berpandangan bahwa Seorang pemimpin perlu memiliki pemahaman yang luas tentang beragam pengetahuan meskipun pemahamannya tidak secara komprehensif. Bagi seorang pemimpin pengetahuan tersebut akan menjadi acuan dalam pengambilan keputusan. Kepemimpinan dapat dikatakan efektif apabila mampu menciptakan situasi yang dapat memberi inspirasi bagi para pengikutnya untuk mencapai tujuan yang lebih baik dan lebih maju lagi dari keadaan sekarang. Tidak hanya memiliki pengetahuan, seorang pemimpin harus memiliki sikap dan tindakan yang digunakan untuk menciptakan iklim organisasi yang baik, hal ini ditujukan agar dapat mencapai sasaran yaitu meningkatkan kualitas pelayanan pada lembaga pelayanan sosial. Ketiga komponen tersebut dapat mempengaruhi dalam menjalankan tugasnya serta menjadi indikator keberhasilan seorang pemimpin dalam memberikan pelayanan di lembaga pelayanan sosial kemanusiaan. 


\section{Simpulan dan saran}

Konsep kepemimpinan yang baik adalah pemimpin yang mampu dan dapat mengelola sumber daya lembaga pelayanan sosial untuk mencapai tujuannya. Peran seorang pemimpin seringkali dilihat sebagai faktor utama dalam mengkoordinasikan dan menyelaraskan proses organisasi lembaga. Ketika memimpin sebuah lembaga pelayanan sosial kemanusiaan, seorang pemimpin harus memiliki kompetensi yang menjadi aspek penunjang dalam menjalani tugasnya. Adapun kompetensi yang harus dimiliki seorang pemimpin yakni: pengetahuan, sikap dan tindakan. Ketiga kompetensi administrator pekerjaan sosial telah diterapkan oleh kepala panti asuhan masyithoh dalam menjalankan peran dan tugasnya sebagai pemimpin. Pemimpin dalam sebuah lembaga pelayanan kemanusiaan harus memiliki kompetensi yang baik demi kelangsungan kegiatan di lembaga tersebut. Salah satu upaya untuk meningkatkan kualitas kompetensi kepemimpinan menjadi tanggung jawab bagi pemimpin itu sendiri. Jika pemimpin memiliki kompetensi yang baik, maka untuk kedepannya akan lebih mudah menghadapi tantangan yang ada di organisasi sosial.

Lembaga Kesejahteraan Sosial Anak Panti Asuhan Masyithoh merupakan salah satu organisasi pelayanan kemanusiaan (Human services organization) berperan untuk memberikan perlindungan kepada anak serta dapat memenuhi hak-hak anak yang sebelumnya mereka tidak mendapatkan pemenuhan hak tersebut. Lembaga telah melaksanakan program untuk membantu pemerintah dalam bidang kesejahteraan sosial anak. Panti Asuhan Masyithoh mengasuh dan membina anak-anak serta memberikan pendidikan formal dari tingkat sekolah dasar sampai dengan sekolah menengah atas. Organisasi layanan manusia sebagai pelaksana dalam menangani masalah sosial di masyarakat selalu berusaha menjalankan tugas dan fungsinya menjadi tempat penanganan masalah sosial yang dapat membantu masyarakat, namun dalam LKSA Panti Asuhan Masyithoh belum terdapat adanya keberadaan pekerja sosial dimana merupakan profesi yang bisa menyelesaikan persoalan dengan baik dan profesional. Oleh karena itu, dalam pelaksanaan praktik di LKSA Panti Asuhan Masyithoh perlunya melibatkan pekerja sosial dalam menangani permasalahan yang ada di LKSA Panti Asuhan Masyithoh.

\section{Daftar Rujukan}

Ahyar, H., Maret, U. S., Andriani, H., Sukmana, D. J., Mada, U. G., Hardani, S.Pd., M. S., Nur Hikmatul Auliya, G. C. B., Helmina Andriani, M. S., Fardani, R. A., Ustiawaty, J., Utami, E. F., Sukmana, D. J., \& Istiqomah, R. R. (2020). Buku Metode Penelitian Kualitatif \& Kuantitatif. Cv. Pustaka Ilmu Group.

Alfiyah, N. I., \& Syafriani, I. (2019). Peran Pemimpin Transformasional dalam Penguatan Kelembagaan (Studi di Dinas Koperasi UMKM, Kabupaten Sumenep). Journal of Governance Innovation, 1(2), 37-48. https://doi.org/10.36636/jogiv.v1i2.341

Creswell, J. W. (2014). Research Design (Quantitative, Qualitative, and Mixed Method). United Kingdom: SAGE Publication, Inc.

Hasenfeld, Y. (2010). Human Services as Complex Organizations (2nd editio). SAGE Publications, Inc. Kouzes, J.,\&Posner, B. (2002). The leadership challenge (3rd ed.). San Francisco: Jossey-Bass.

Obsorne, C. (2015). Essential Managers Leadership (L. Tucker (ed.)). A Penguin Random House Company.

Packard, T. (2020). Leadership and Performance in Human Services Organizations. In Leadership and Performance in Human Services Organizations (Issue January 2020, pp. 143-164). San Diego State University.

Saldana, J. (2009). The Coding Manual for Qualitative Researchers. London: Sage Publications

Skidmore, R. A. (1995). Social Work Administration: Dynamic Management and Human Relationships. United States: Allyn and Bacon.

Soehartono, I. (2015). Metode Penelitian Sosial. Bandung: PT Remaja Rosdakarya. 
Suparno. (2012). Peran Kepemimpinan Dalam Pengambilan Keputusan. Mimbar Administrasi FISIP UNTAG Semarang, 6, 1-20. https://doi.org/10.31227/osf.io/d8nzv 